\title{
EFFICACY OF CETUXIMAB/PANITUMUMAB AFTER PREVIOUS BEVACIZUMAB IN METASTATIC COLORECTAL CANCER
}

\author{
ALEXANDRA GHERMAN ${ }^{1 \#}$, CĂLIN CAINAP ${ }^{1,2}$, ȘTEFAN-CRISTIAN VESA $^{3}$, ANDREI DAN $^{2}$ \\ HAVASI $^{2}$, ALEXANDRA TRIFON $^{4}$, SIMONA SORANA CAINAP ${ }^{5,6 *}$, OVIDIU CRIȘAN $^{7 \#}$, \\ ALEXANDRU IRIMIE ${ }^{8,9}$
}

\author{
${ }^{1} 11^{\text {th }}$ Department of Medical Oncology, "Iuliu Hațieganu” University of Medicine and Pharmacy, Cluj-Napoca, Romania \\ ${ }^{2}$ Department of Medical Oncology, The Oncology Institute "Prof. Dr. Ion Chiricuță”, Cluj-Napoca, Romania \\ ${ }^{3}$ Department of Pharmacology, Toxicology and Clinical Pharmacology, "Iuliu Hațieganu” University of Medicine and \\ Pharmacy, Cluj-Napoca, Romania \\ ${ }^{4}$ The Regional Institute of Gastroenterology and Hepatology "Prof. Dr. O. Fodor", Cluj-Napoca, Romania \\ ${ }^{5}$ Department of Paediatric Cardiology, Emergency County Hospital for Children, Pediatric Clinic no 2, Cluj-Napoca, Romania \\ ${ }^{6}$ Department of Mother and Child, "Iuliu Hațieganu” University of Medicine and Pharmacy, Cluj-Napoca, Romania \\ ${ }^{7}$ Department of Organic Chemistry, "Iuliu Hațieganu” University of Medicine and Pharmacy, Cluj-Napoca, Romania \\ ${ }^{8} 11^{\text {th }}$ Department of Oncological Surgery and Gynaecological Oncology, "Iuliu Hațieganu” University of Medicine and \\ Pharmacy, Cluj-Napoca, Romania \\ ${ }^{9}$ Department of Surgery, The Oncology Institute "Prof. Dr. Ion Chiricuță”, Cluj-Napoca, Romania
}

*corresponding author: cainap.simona@gmail.com

${ }^{\#}$ Authors with equal contribution.

Manuscript received: February 2020

\begin{abstract}
The optimal sequence of the targeted therapies in metastatic colorectal cancer is not established. We aimed to analyse if previous administration of bevacizumab impacts the response to epidermal growth factor receptor inhibitors in subsequent lines of therapy. It was performed a retrospective analysis on KRAS or KRAS/NRAS wild-type metastatic colorectal cancer patients that received an epidermal growth factor receptor inhibitor in the second or later lines of therapy and their outcomes were analysed according to previous exposure to bevacizumab. 85 metastatic colorectal cancer patients were included, of whom 22 had received previous chemotherapy (group A) and 63 previous chemotherapy plus bevacizumab (group B). The overall survival was significantly higher in the group B (35.6 months versus 24.8 months, $p=0.01$ ). The overall survival and progression-free survival calculated from the start of the epidermal growth factor receptor inhibitor did not significantly differ between the groups. The multivariate analysis revealed that using bevacizumab did not significantly impact the survival. Our results show that previous administration of bevacizumab does not influence the efficacy of epidermal growth factor receptor inhibitors in later lines of treatment.
\end{abstract}

\section{Rezumat}

Secvența optimă a tratamentelor moleculare țintite în cancerul colorectal metastatic încă nu este stabilită. Obiectivul studi ului a fost de a analiza dacă răspunsul terapeutic la inhibitorii receptorului factorului de creștere epidermal în liniile ulterio are de tratament este influențat de administrarea anterioară de bevacizumab. A fost efectuată o analiză retrospectivă a pacienților cu cancer colorectal metastatic fără mutații KRAS sau KRAS/NRAS, care au primit tratament cu un inhibitor al receptorului factorului de creștere epidermal în linia a doua sau ulterioară de tratament și a fost analizată evoluția clinică a pacienților în funcție de expunerea anterioară la bevacizumab. În studiu au fost incluși 85 pacienți cu cancer colorectal metastatic, dintre care 22 au primit chimioterapie anterioară singură (grupul A), iar 63 au primit chimioterapie anterioară cu bevacizumab (grupul B). Supraviețuirea globală a fost semnificativ mai mare în grupul B $(35,6$ luni versus 24,8 luni, $p=0,01)$. Supraviețuirea globală și supraviețuirea liberă de progresia bolii calculate de la debutul liniei cu agentul inhibitor al receptorului factorului de creștere epidermal nu a fost semnificativ diferită între cele două grupuri. Analiza multivariată a supraviețuirii a arătat că administrarea bevacizumabului nu a influențat semnificativ supraviețuirea. Rezultatele studiului arată că administrarea anterioară de bevacizumab nu influențează eficiența inhibitorilor factorului de creștere epidermal în liniile ulterioare de tratament.

Keywords: colorectal cancer, EGFR inhibitors, sequence, bevacizumab

\section{Introduction}

Colorectal cancer (CRC) is the third most diagnosed cancer and the second cause of cancer-related death, worldwide [1]. More than $50 \%$ of all CRC patients will develop metastases during the course of the disease, either synchronous or metachronous [14]. Metastatic disease has a poor prognosis, with 5-year relative survival rates only reaching $13.1 \%$ [6]. The clinical 
FARMACIA, 2020, Vol. 68, 4

outcomes have greatly improved in stage IV patients, with a median overall survival (OS) reaching 30 months, due to better management that uses a "treatment continuum". This therapeutic approach encompasses the sequential administration of systemic drugs and local treatments for the primary tumour and/or metastases, where feasible [25].

Chemotherapy regimens for RAS wild-type metastatic colorectal cancer (mCRC) are most commonly based on fluoropyrimidines (5-fluorouracil or capecitabine), oxaliplatin or irinotecan and are usually associated with molecular targeted treatments, according to the treatment line, usually an inhibitor of the epidermal growth factor receptor (EGFRI) - cetuximab or panitumumab or an antiangiogenic - bevacizumab, aflibercept, ramucirumab, regorafenib. The associations could have different toxicities depending on multiple factors [3].

When it comes to choices for first- and further-line therapies, up to date there is no unequivocal evidence on the optimal treatment sequence and it has become clear that all cytotoxic agents previously mentioned and all targeted therapies, EGFR inhibitors (EGFRIs) and antiangiogenics, have to be administered at some point during the course of the disease for "fit" patients. According to the European Society for Medical Oncology Guidelines, the aim is that $70-80 \%$ of patients receive second-line and $50-60 \%$ third-line therapy [25]. In first-line all-RAS wild-type mCRC, clinical trials could not establish an absolute superiority of a targeted agent (EGFRI or bevacizumab) in the detriment of the other, although post-hoc analyses of the FIRE-3 [22] (in Germany - Austria) and CALGB trial [26] (in US) showed a major impact of primary tumour location on survival: left-sided, RAS wild-type tumours benefited the most, while right-sided tumours did not benefit at all from the EGFRIs. In FIRE-3, but not CALGB trial, patients treated with first-line cetuximab had higher OS than those with first-line bevacizumab. Also, a meta-analysis performed on $2576 \mathrm{mCRC}$ patients, RAS wild-type, in order to determine which agent renders better outcomes in first-line showed better OS, higher objective response rates and more complete responses for patients receiving first-line cetuximab versus bevacizumab [29]. Nevertheless, a systematic review and meta-analysis performed on seventeen randomized trials in first-line $\mathrm{mCRC}$ did not confirm the superiority of EGFRIs over bevacizumab in terms of OS and progression-free survival (PFS) [13]. The benefits of bevacizumab in first-line mCRC exist regardless the KRAS gene status [12].

After failure of first-line treatment, in the second-line, fit patients with good performance status should receive either the re-introduction of the first-line chemotherapy after a de-escalation maintenance, or a different chemotherapy backbone than in first-line, any of the above combined with a biological agent: an antiangiogenic if none administered in first-line (bevacizumab or aflibercept) or, if patients had first-line bevacizumab, either bevacizumab beyond progression or ramucirumab. Clinical trials showed that the administration of an antiangiogenic in the second line improved OS. If an EGFRI (cetuximab or panitumumab) is not administered in first-line, it should be considered in second-line, but the survival benefits are similar when used in second or subsequent lines [25]. An analysis of the impact of subsequent treatments on survival, performed on KRAS exon 2 wild-type tumours in the FIRE-3 clinical study, pointed out better second-line PFS in patients receiving chemotherapy plus bevacizumab than in patients receiving chemotherapy plus cetuximab [18]. In the present study, we aimed to test the hypothesis that previous administration of bevacizumab impacts the benefits of subsequent EGFRI administered in further lines, by retrospectively analysing the outcomes of the patients treated in a tertiary care oncology centre.

\section{Materials and Methods}

Study population: We conducted a retrospective analysis that included consecutive patients addressed to our tertiary care oncology centre between January 2007 and December 2017 and treated for mCRC, with available information regarding demographics, tumour and disease characteristics, treatments received and clinical outcomes. The study was approved by the Ethics Committee of the "Prof. Dr. Ion Chiricuță" Institute of Oncology Cluj-Napoca, Romania, No 42/ $8^{\text {th }}$ December 2015. All data regarding patients were obtained from the Institutional Cancer Registry.

We included patients that had a histologically confirmed diagnosis of CRC with distant metastases either from the initial diagnosis (synchronous) or after recurrence (metachronous), KRAS exon 2 wild-type or KRAS/ NRAS (all-RAS) exons 2,3,4 wild-type tumours. Because this was a retrospective study and patients were treated during an eleven years period, the mutational status of KRAS or KRAS/NRAS genes was performed at the time of treatment for each individual patient, according to international guidelines. Included patients did not have any medical contraindication to chemotherapy, bevacizumab or cetuximab/panitumumab had an adequate follow-up (at least monthly clinical check-up and CTscans every 3 to 4 months).

We identified 85 eligible patients with $\mathrm{mCRC}$ that received an EGFRI in second or later lines of therapy and divided them into two groups according to the treatment received: chemotherapy alone followed at disease progression by cetuximab/panitumumab (group $\mathrm{A}=22$ ) or chemotherapy plus bevacizumab followed in subsequent lines of therapy by cetuximab/ panitumumab (group $B=63$ ). EGFRIs were administered as single agents or combined with chemotherapy. Individual choices of treatment and sequences were made at the time by referring physicians. 
Treatments and response evaluation: Chemotherapy, bevacizumab, and cetuximab/panitumumab were administered according to international or institutional guidelines available at the time of treatment. Delays or dose adjustments were made whenever considered necessary by the referring oncologist. bevacizumab was administered every 2 or 3 weeks, according to the chemotherapy regimen, at a dose equivalent to $2.5 \mathrm{mg} / \mathrm{kg}$ b.w./week. Cetuximab was administered at an initial dose of $400 \mathrm{mg} / \mathrm{m}^{2}$, followed by subsequent weekly doses of $250 \mathrm{mg} / \mathrm{m}^{2}$. Panitumumab was administered at a dose of $6 \mathrm{mg} / \mathrm{kg}$ b.w. every 2 weeks. Response evaluation was performed on computed tomography assays according to RECIST 1.1.

Endpoints: The main endpoints were OS and progressionfree survival (PFS) for the EGFRI treatment-line. Both OS and PFS were calculated from the date of starting the EGFR inhibitors to death and disease progression, respectively OS was also calculated from the initial administration of first-line metastatic treatment to death (total OS).

We also analysed parameters known to affect patients' survival outcomes: demographic data, tumour-sidedness, RAS mutational status (KRAS or all-RAS wild type), number and location of metastatic sites (liver, lung, peritoneum, other), metastases type (synchronous/ metachronous), whether surgery was performed on primary tumour and/or metastases, the EGFRI treatment line, chemotherapy associated with the EGFRI (oxaliplatin-based, irinotecan-based, fluoropyrimidine alone, none). Right-sided primary tumours included tumours located proximally to the splenic flexure, while leftsided primaries were the tumours located distally to the splenic flexure, including the rectum. The metachronous disease was considered when metastases occurred at $>6$ months after the initial diagnosis of CRC. Although two EGFRIs (cetuximab or panitumumab) were used, they were analysed together as their efficacy is considered to be similar in $\mathrm{mCRC}$ patients.

Statistical analysis was performed using the MedCalc Statistical Software version 19.1.5 (MedCalc Software bv, Ostend, Belgium). Quantitative data is described by median and 25 - 75 percentiles while nominal data is expressed as frequency and percentage. A comparison between groups was carried out with the Man-Whitney test or chi-square test, whenever appropriate. Univariate survival analysis was performed using the KaplanMeier test. Multivariate analysis for survival was carried out using the Cox regression. A p-value $<0.05$ was considered statistically significant.

\section{Results and Discussion}

The characteristics of the study groups are presented in Table I. There were no differences between groups regarding the age or gender of the patients. Cancer location and number of metastatic sites did not differ between groups. Group B had significantly more liver metastases, synchronous metastases and received cetuximab in the third or later lines of treatment. The total OS was also longer in group B.

Table I

Characteristics of study groups

\begin{tabular}{|c|c|c|c|c|c|}
\hline \multicolumn{3}{|l|}{ Variable } & Group A $(n=22)$ & Group B $(n=63)$ & $\mathrm{p}$ \\
\hline \multicolumn{3}{|l|}{ Age (years) } & $58.5(51.5 ; 58.5)$ & $58(54 ; 64)$ & 0.3 \\
\hline \multirow[t]{2}{*}{ Gender } & \multicolumn{2}{|l|}{ Male } & $13(59.1 \%)$ & $32(50.8 \%)$ & \multirow[t]{2}{*}{0.6} \\
\hline & \multicolumn{2}{|l|}{ Female } & $9(40.9 \%)$ & $31(49.2 \%)$ & \\
\hline \multirow{2}{*}{\multicolumn{2}{|c|}{ Location of the primary tumour }} & Right-sided & $3(13.6 \%)$ & $12(19 \%)$ & \multirow[t]{2}{*}{0.7} \\
\hline & & Left-sided & $19(86.4 \%)$ & $51(81 \%)$ & \\
\hline \multirow[t]{2}{*}{ Metastases } & \multicolumn{2}{|l|}{$<2$} & $15(77.3 \%)$ & $54(85.7 \%)$ & \multirow[t]{2}{*}{0.5} \\
\hline & \multicolumn{2}{|l|}{$\geq 2$} & $5(22.7 \%)$ & $9(14.3 \%)$ & \\
\hline \multicolumn{3}{|l|}{ Liver metastases } & $12(54.5 \%)$ & $50(79.4 \%)$ & 0.04 \\
\hline \multicolumn{3}{|l|}{ Lung metastases } & $7(31.8 \%)$ & $9(14.3 \%)$ & 0.1 \\
\hline \multicolumn{3}{|c|}{ Peritoneal metastases } & $2(9.1 \%)$ & $7(11.1 \%)$ & 1 \\
\hline \multicolumn{3}{|c|}{ Other locations of metastases } & $5(22.7 \%)$ & $9(14.3 \%)$ & 0.5 \\
\hline \multirow[t]{2}{*}{ Metastasis type } & \multicolumn{2}{|c|}{ metachronous } & $11(50 \%)$ & $14(22.2 \%)$ & \multirow[t]{2}{*}{0.02} \\
\hline & \multicolumn{2}{|c|}{ synchronous } & $11(50 \%)$ & $49(77.8 \%)$ & \\
\hline \multicolumn{3}{|c|}{ All RAS wild type } & $12(54.5 \%)$ & $40(63.5 \%)$ & \multirow[t]{2}{*}{0.6} \\
\hline \multicolumn{3}{|c|}{ KRAS wild type } & $10(45.5 \%)$ & $23(36.5 \%)$ & \\
\hline \multirow{2}{*}{\multicolumn{2}{|c|}{ Cetuximab line of treatment }} & 2 & $11(50 \%)$ & $15(23.8 \%)$ & \multirow[t]{2}{*}{0.04} \\
\hline & & $\geq 3$ & $11(50 \%)$ & $48(76.2 \%)$ & \\
\hline \multicolumn{3}{|c|}{ Primary tumour resection } & $17(77.3 \%)$ & $55(87.3 \%)$ & 0.3 \\
\hline \multicolumn{3}{|c|}{ Metastases resection } & $8(36.4 \%)$ & $23(36.5 \%)$ & 1 \\
\hline \multirow{4}{*}{\multicolumn{2}{|c|}{ Chemotherapy backbone }} & None & $7(31.8 \%)$ & $12(19 \%)$ & \multirow[t]{4}{*}{0.3} \\
\hline & & $5-\mathrm{FU}$ & - & $1(1.6 \%)$ & \\
\hline & & Irinotecan-based & $11(50 \%)$ & $43(68.3 \%)$ & \\
\hline & & Oxaliplatin-based & $4(18.2 \%)$ & $7(11.1 \%)$ & \\
\hline \multicolumn{3}{|c|}{ PFS 2 (months) } & $5.9(3.9 ; 10.1)$ & $6.5(3.7 ; 10.2)$ & 0.9 \\
\hline \multicolumn{3}{|c|}{ Total OS (months) } & $24.8(14.2 ; 38.8)$ & $35.6(24 ; 49.3)$ & 0.01 \\
\hline
\end{tabular}


FARMACIA, 2020, Vol. 68, 4

\begin{tabular}{|l|c|c|c|}
\hline OS from the start of cetuximab therapy & $10.2(5.1 ; 22.6)$ & $10.3(5.4 ; 17.8)$ & 0.8 \\
\hline
\end{tabular}

We did not find any associations between PFS under EGFRI and other variables.

The median interval from the last dose of bevacizumab and the first dose of cetuximab was 45 days.

Data concerning patients' survival is revealed in Table II.

Table II

Analysis of survival

\begin{tabular}{|c|c|c|c|c|c|c|c|}
\hline \multicolumn{4}{|c|}{ Variable } & Deceased $(n=69)$ & Survivors $(\mathrm{n}=16)$ & $\mathrm{HR}^{*}(95 \% \mathrm{CI})$ & p-value \\
\hline \multirow[t]{2}{*}{ Group } & \multicolumn{3}{|l|}{$\mathrm{A}$} & $18(26.1 \%)$ & $4(25 \%)$ & \multirow[t]{2}{*}{$1.7(1-3)$} & \multirow[t]{2}{*}{0.04} \\
\hline & \multicolumn{3}{|l|}{$\mathrm{B}$} & $51(73.9 \%)$ & $12(75 \%)$ & & \\
\hline \multicolumn{4}{|l|}{ Age } & $56(50.5 ; 65)$ & $62(59 ; 66.5)$ & $0.98(0.9-1)$ & 0.3 \\
\hline \multirow[t]{2}{*}{ Gender } & \multicolumn{3}{|c|}{ Female } & $35(50.7 \%)$ & $5(31.3 \%)$ & \multirow[t]{2}{*}{$0.84(0.5-1.2)$} & \multirow[t]{2}{*}{0.4} \\
\hline & \multicolumn{3}{|c|}{ Male } & $34(49.3 \%)$ & $11(68.8 \%)$ & & \\
\hline \multirow{2}{*}{\multicolumn{3}{|c|}{$\begin{array}{l}\text { Location of the primary } \\
\text { tumour }\end{array}$}} & Right-sided & $33(47.8 \%)$ & $9(56.3 \%)$ & \multirow[t]{2}{*}{$1(0.6-1.6)$} & \multirow[t]{2}{*}{0.8} \\
\hline & & & Left-sided & $36(52.2 \%)$ & $7(43.8 \%)$ & & \\
\hline \multirow{2}{*}{\multicolumn{2}{|c|}{ Metastases }} & \multicolumn{2}{|c|}{$<2$} & $59(85.5 \%)$ & $12(75 \%)$ & \multirow[t]{2}{*}{$1.5(0.7-3.1)$} & \multirow[t]{2}{*}{0.2} \\
\hline & & \multicolumn{2}{|c|}{2} & $10(14.5 \%)$ & $4(25 \%)$ & & \\
\hline \multicolumn{4}{|c|}{ Liver metastases } & $52(75.4 \%)$ & $10(62.5 \%)$ & $1.1(0.6-2)$ & 0.5 \\
\hline \multicolumn{4}{|c|}{ Lung metastases } & $14(20.3 \%)$ & $2(12.5 \%)$ & $1.8(1-3.3)$ & 0.04 \\
\hline \multicolumn{4}{|c|}{ Peritoneal metastases } & $8(11.6 \%)$ & $1(6.3 \%)$ & $2(0.9-4.2)$ & 0.07 \\
\hline \multicolumn{4}{|c|}{ Other locations of metastases } & $8(11.6 \%)$ & $6(37.5 \%)$ & $0.81(0.3-1.6)$ & 0.5 \\
\hline \multirow{2}{*}{\multicolumn{2}{|c|}{ Metastasis type }} & \multicolumn{2}{|c|}{ metachronous } & $18(26.1 \%)$ & $7(43.8 \%)$ & \multirow[t]{2}{*}{$1.1(0.6-1.8)$} & \multirow[t]{2}{*}{0.8} \\
\hline & & \multicolumn{2}{|c|}{ synchronous } & $51(73.9 \%)$ & $9(11 \%)$ & & \\
\hline \multicolumn{4}{|c|}{ All-RAS wild-type } & $36(52.2 \%)$ & $16(100 \%)$ & $0.47(0.2-0.7)$ & 0.003 \\
\hline \multirow{2}{*}{\multicolumn{3}{|c|}{ Cetuximab line of treatment }} & 2 & $18(26.1 \%)$ & $8(50 \%)$ & \multirow[t]{2}{*}{$0.74(0.4-1.2)$} & \multirow[t]{2}{*}{0.2} \\
\hline & & & $\geq 3$ & $51(73.9 \%)$ & $8(50 \%)$ & & \\
\hline \multicolumn{4}{|c|}{ Primary tumour resection } & $56(81.2 \%)$ & $16(100 \%)$ & $0.51(0.2-0.9)$ & $\mathbf{0 . 0 3}$ \\
\hline Metasta & resec & & & $23(33.3 \%)$ & $8(50 \%)$ & $0.52(0.3-0.8)$ & 0.01 \\
\hline
\end{tabular}

Table III

Multivariate analysis of survival

\begin{tabular}{|l|c|c|c|c|c|}
\hline & B & P & \multirow{2}{*}{ HR } & \multicolumn{2}{|c|}{$95.0 \%$ CI for HR } \\
\cline { 4 - 6 } & & & & Min & Max \\
\hline Group B & -0.09 & 0.7 & 0.90 & 0.49 & 1.66 \\
\hline Lung metastases & 0.62 & 0.06 & 1.87 & 0.97 & 3.59 \\
\hline Peritoneal metastases & 1.36 & 0.001 & 3.92 & 1.69 & 9.06 \\
\hline All RAS wild-type & -0.89 & 0.001 & 0.40 & 0.24 & 0.69 \\
\hline Primary tumour resection & -0.81 & 0.02 & 0.44 & 0.21 & 0.89 \\
\hline Metastases resection & -0.43 & 0.1 & 0.64 & 0.37 & 1.12 \\
\hline
\end{tabular}

Multivariate analysis of survival was carried out in order to better understand the factors that influenced independently the mortality, as seen in Table III. The presence of peritoneal metastases greatly enhanced the probability of death. The presence of all RAS wild-type and primary tumour resection was associated with increased survivability.

Patients from group A were significantly more likely to die as compared to patients in group B (Figure 1A). Patients with lung metastases (Figure 1B) or peritoneal metastases (Figure 1C), patients with KRAS wild-type (versus all RAS wild-type) (Figure 1D), with un-resected primary tumour (Figure 1E) or patients who did not go through with metastases resection (Figure 1F), had a higher probability of dying.

The question whether bevacizumab negatively impacts the response to further-line cetuximab/panitumumab in mCRC is raised because of the patients' outcomes seen in clinical trials, together with the pharmacokinetics particularities of bevacizumab and the preclinical data on in vitro and in vivo models regarding mechanisms of resistance to EGFRIs.

Bevacizumab has a long half-life of approximately 20 days (ranging from 11 to 50 days) [20]. A pharmacokinetic study performed on stage II-III CRC patients treated with adjuvant bevacizumab for one year within the AVF3077 study, showed persistent serum concentration at 3 and 6 months after the last administered dose. As previously stated by the authors of this study, it is important to take this into consideration when response assessments to further therapies after bevacizumab are performed [15]. In vitro studies show that bevacizumab resistant CRC cells present higher autocrine HIFVEGF signalling and resistance to hypoxia [16]. Wang 
FARMACIA, 2020, Vol. 68, 4

et al. [28], proved that in CRC cells, an important role in resistance to EGFR inhibitors is played by HIF-1 alfa. A previous study showed increased levels of plasmatic VEGF-A in mCRC patients after bevacizumab

A

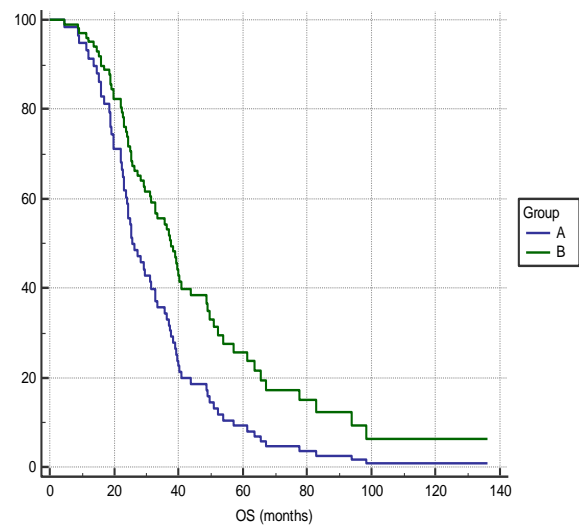

C



$\mathbf{E}$

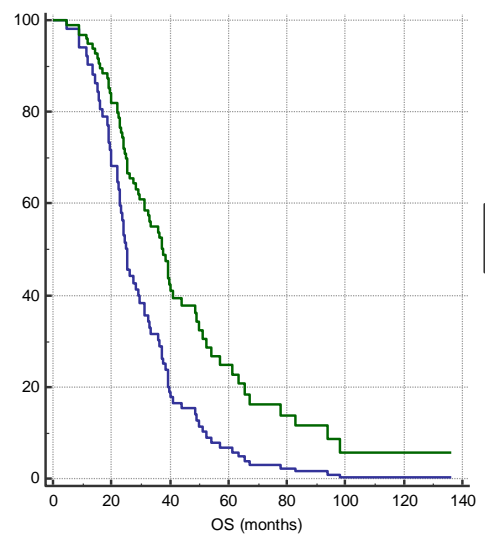

administration and on in vitro studies, the same authors proved that CRC cells exposed to VEGF-A become resistant to the EGFRI through VEGFR-2 and Stat-3 activation [5].
B

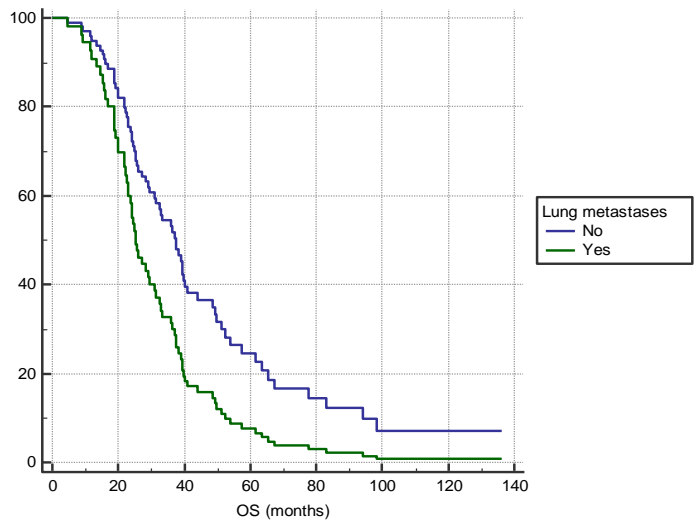

D

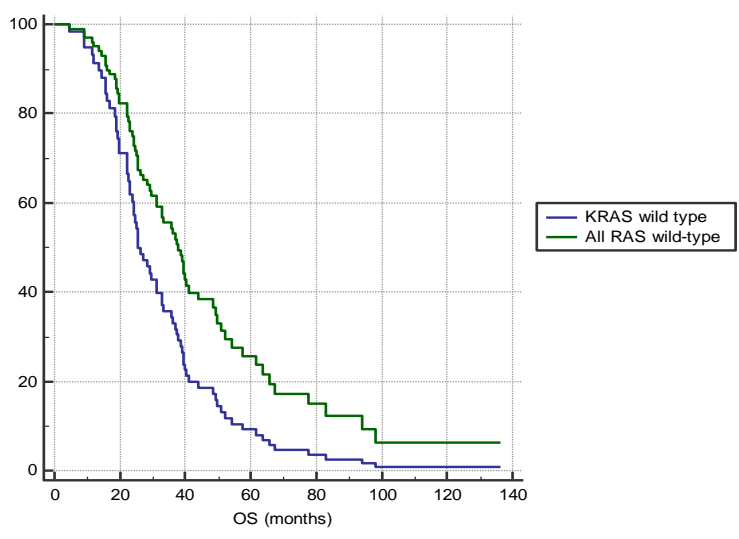

$\mathbf{F}$

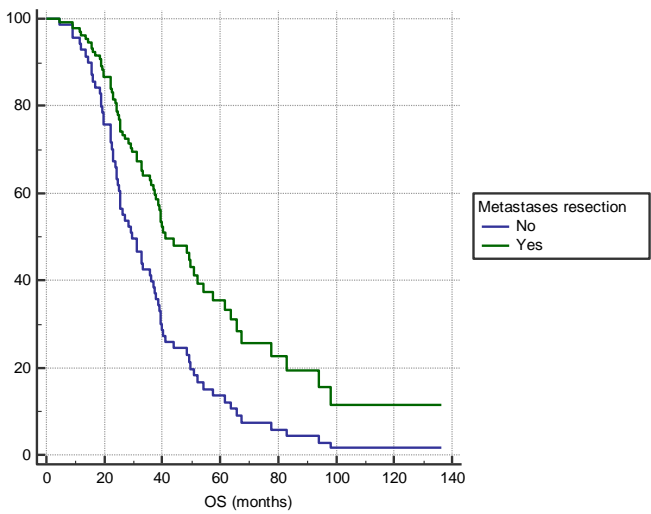

Figure 1.

Kaplan-Meier curves of overall survival according to: (A) treatment group - group A without bevacizumab, group B with bevacizumab, $\mathrm{p}=0.04$; (B) presence of lung metastases, $\mathrm{p}=0.04$; (C) presence of peritoneal metastases, $\mathrm{p}=0.07$; (D) RAS mutational status, $\mathrm{p}=0.003$; (E) primary tumour resection, $\mathrm{p}=0.03$;

(F) metastases resection, $\mathrm{p}=0.01$

Although preclinical trials showed that the two biologicals (EGFRI and bevacizumab) have additive antitumoural effects [4], clinical trials have shown that the combination is detrimental. CAIRO-2 was a prospective, randomized phase 3 clinical trial on $755 \mathrm{mCRC}$ patients that aimed to establish whether 
FARMACIA, 2020, Vol. 68, 4

first-line PFS was improved if an EGFRI - cetuximab was added to first-line CAPOX + bevacizumab; the study was performed in an unselected population regarding the RAS mutational status and used the combination of capecitabine + cetuximab, and is no longer recommended today due to the higher toxicity. PFS was significantly higher in the group without cetuximab (10.7 months versus 9.4 months, $\mathrm{p}=0.01$ ) [24]. The PACCE trial [10] was performed on 1053 mCRC patients that were randomized to receive either chemotherapy (oxaliplatin or irinotecan-based) plus bevacizumab, or chemotherapy plus bevacizumab plus panitumumab. The primary end-point, PFS within oxaliplatin cohort $(\mathrm{n}=823)$, was of 10.0 versus 11.4 months (HR, $1.27 ; 95 \% \mathrm{CI}, 1.06$ to 1.52 ) and also toxicity was higher for the combination, proving the detrimental effect of adding the second biological and possible due to allergic reaction to oxaliplatin [8]. The study treatment was administered to an unselected RAS population (40\% had KRAS mutations).

Hsu and colleagues questioned the best sequence of the two targeted treatments (EGFRIs and anti-VEGFs) in mCRC. They performed a retrospective analysis on 102 mCRC patients, KRAS wild-type, of whom 46 received first-line cetuximab and third-line bevacizumab and 56 received the reverse sequence, first-line bevacizumab and third-line cetuximab. The first group had significantly better total OS and OS calculated from the start of second and third-line treatment (30.4 vs. 25.7 months, 20.6 vs. 14.8 months and 12.5 vs. 9.9 months, respectively). Regarding the PFS, only third-line PFS was significantly better in the cetuximabbevacizumab sequence [11].

The results of our study show that previous bevacizumab does not alter the clinical outcomes in patients receiving subsequent EGFRIs. The PFS for the EGFRIregimen was not different between the groups. Although, patients in group B (chemotherapy plus bevacizumab before treatment with EGFRIs) had more synchronous metastases and liver metastases, both known to be associated with poor prognosis and $76.2 \%$ received the EGFRI in later lines of treatment ( $\geq$ third line) versus $50 \%$ in group $\mathrm{A}$, they had a significantly higher OS, with a median of 35.6 months versus 24.8 months. We also assessed the OS from the start of the EGFRI in order to exclude the potential benefit of prior therapies on OS and there was no significant difference between the groups. Taking all these into consideration, we wanted to further investigate if prior bevacizumab was responsible for better outcomes in group B or there were also other factors. In the univariate analysis of survival, patients from group A, patients with lung metastases, peritoneal metastases, un-resected primary tumour and patients without resection of metastases had a significantly higher probability of dying. Nonetheless, underlying the importance of other variables, in the multivariate analysis prior treatment with bevacizumab did not affect significantly the outcome. Other factors had a significant impact on the probability of dying: patients with peritoneal metastases and un-resected primary tumour were more prone to die, while all-RAS wild type versus KRAS wild-type status was correlated with a better survival rate. The relatively small number of patients did not validate the predictive status for survival of some parameters (e.g. location of the primary tumour).

Lung metastases are more frequently associated with rectal tumours compared to colon tumours and in the vast majority of cases are disseminated and therefore, inoperable. If surgery is not performed, their prognosis remains poor [17].

Peritoneal metastases are well-known to carry a poor prognosis and their resection has no benefit. An analysis on $10553 \mathrm{mCRC}$ patients included in 14 clinical trials (from the ARCAD database) showed that $2 \%$ of them had peritoneum-only metastases and $11 \%$ peritoneum and other site; OS for peritonealonly was significantly worse than for other unique metastatic site and the differences became even more marked in patients that received chemotherapy plus targeted therapies [7]. In peritoneum-only metastatic patients, there was a significantly higher proportion of BRAF-mutated patients (18\%), also in multiple metastatic sites including the peritoneum $(12 \%)$ when compared to patients with other non-peritoneal sites, solitary or multiple $(9 \%)$. BRAF mutations are of negative prognosis and they are associated with poor response to anti-EGFR agents, especially in second and further lines of therapy [21]. We have no information regarding the BRAF mutational status in our patients. Multiple clinical studies were conducted with the purpose of establishing the benefits in performing surgery for the asymptomatic primary tumour in stage IV disease with un-resectable metastases. A retrospective study on 1446 mCRC treated between 2003 and 2006, out of which $16 \%$ had resection of the primary tumour without metastasectomy, showed better OS for the resected group [9]. At that time, however, systemic treatment options were limited. In a more recent analysis on 26170 mCRC patients diagnosed between 2010 and 2016 (the SEER database), there was an important survival benefit in patients that had surgery for the primary tumour and chemotherapy as the first choice of treatment [27].

Because this was a retrospective study and we did not have access to tumour blocks, we could not assess the all-RAS mutational status in our patients. Today it is well-known that patients with mutations in the KRAS exons 2,3,4 and NRAS exons 2,3,4 do not respond to EGFRIs, but the assessment of the NRAS status was recommended and became mandatory only starting 2014. Almost $40 \%$ of our patients were only known to be KRAS exon 2 wild-type, without available information regarding the KRAS exons 3,4 and NRAS status, while the remainder $60 \%$ was all-RAS wild- 
type. Most probably, additional mutations were present in the KRAS exon 2 wild-type patients, fact that could explain why the all-RAS wild-type was a marker of significant better survival in a population with $100 \%$ KRAS wild-type.

Other research groups also studied the effect of previous bevacizumab on clinical outcomes of patients treated with an EGFRI. Burge and colleagues performed a retrospective study that included 222 RAS wild-type mCRC patients treated with an EGFRI in second or third-line, out of which $77 \%$ received previous bevacizumab. OS and PFS were calculated from the start of the EGFRI to death and progressive disease, respectively. Their results showed that there was no impact of prior bevacizumab treatment neither on OS, nor on PFS. A median interval of 6 months from the last dose of bevacizumab to the first dose of cetuximab was reported and they further split the group that received previous bevacizumab into two $(<6$ months vs. $>6$ months) and found that an interval of $<6$ months was associated with lower PFS, but only in right-sided tumours [2]. A different study showed that the shorter the interval, the higher the probability of interfering with the efficacy of EGFRIs [23]. In our study, the interval was much shorter (1.5 months), so no further analysis was performed in this regard. Another team investigated the effect of prior bevacizumab on treatment with cetuximab in patients experiencing failure on irinotecan. A total of 58 patients were included, among which 13 were pre-treated with bevacizumab; none of the 13 responded to cetuximab and PFS was significantly lower than in the group without prior Bevacizumab [19].

Derangère and colleagues included in their study 128 patients with KRAS/NRAS wild-type mCRC treated with cetuximab or panitumumab in the second- or third-line treatment, as single agents or combined with chemotherapy, of whom 59\% received bevacizumab in the first line. Median PFS during the treatment with the EGFRI was significantly better in the group without previous bevacizumab. However, the OS did not differ [5].

\section{Conclusions}

There was no significant impact of previous bevacizumab on the treatment outcome of patients treated with an EGFRI in subsequent lines of treatment. Although patients receiving both agents had a significantly better OS, the predictors of better survival were allRAS wild-type status and primary tumour resection, while peritoneal metastases were significantly associated with a poorer OS. However, this was a retrospective study with a limited number of patients, without a preplanned sequence of treatments and we did not have all the molecular information available in all patients (e.g. all-RAS and BRAF mutational status). On the other hand, one of the strengths of our study is that it included real-life patients as seen in daily practice and not an over selected population such as patients included in clinical trials. In order to perform better choices of systemic treatment sequences, identification of biomarkers for treatment response is needed and should be addressed by future clinical trials.

\section{Acknowledgement}

The authors A.G. and C.C. were supported by the BIOGENONCO grant, 10/01.09.2016 (MySMIS-Code: 105774).

\section{Conflict of interest}

The authors declare no conflict of interest.

\section{References}

1. Bray F, Ferlay J, Soerjomataram I, Siegel RL, Torre LA, Jemal A, Global cancer statistics 2018: GLOBOCAN estimates of incidence and mortality worldwide for 36 cancers in 185 countries. CA Cancer J Clin., 2018; 68(6): 394-424.

2. Burge M, Semira C, Lee B, Lee M, Kosmider S, Wong R, Shapiro J, Ma B, Dean AP, Zimet AS, Steel SA, Lok SW, Torres J, Eastgate M, Wong HL, Gibbs P, Previous bevacizumab and efficacy of later antiepidermal growth factor receptor antibodies in metastatic colorectal cancer: results from a large international registry. Clin Colorectal Cancer, 2018; 17(3): e593e599.

3. Cainap SS, Nagy V, Cainap C, Chemotherapy induced cardiotoxicity in oncology drugs involved and clinical assessment. Farmacia, 2016; 64(4): 487-492.

4. Ciardiello F, Bianco R, Damiano V, Fontanini G, Caputo R, Pomatico G, De Placido S, Bianco AR, Mendelsohn J, Tortura G, Antiangiogenic and antitumor activity of anti-epidermal growth factor receptor $\mathrm{C} 225$ monoclonal antibody in combination with vascular endothelial growth factor antisense oligonucleotide in human GEO colon cancer cells. Clin Cancer Res., 2000; 6: 3739-3747.

5. Derangère V, Fumet JD, Boidot R, Bengrine L, Limagne E, Chevriaux A, Vincent J, Ladoire S, Apetoh L, Rebe C, Ghiringhelli F, Does bevacizumab impact anti-EGFR therapy efficacy in metastatic colorectal cancer?. Oncotarget, 2016; 7(8): 9309-9321.

6. Damnjanovic I, Kocic G, Najman S, Stojanovic S, Tomovic K, Ilic B, Veljkovic A, Pesic S, Smelcerovic A, Possible molecular mechanisms and pathways involved in $\mathrm{BH} 3$ mimetic activity of alpha-lipoic acid on human colon cancer cell line. Farmacia, 2019; 67(2): 226-234.

7. Franko J, Shi Q, Meyers JP, Maughan TS, Adams RA, Seymour MT Saltz L, Punt CJA, Koopman M, Tournigand C, Tebbutt NC, Diaz-Rubio E, Souglakos J, Falcone A, Chibaudel B, Heineman V, Moen J, De Gramont A, Sargent DJ, Grothey AF, Prognosis of patients with peritoneal metastatic colorectal cancer given systemic therapy: an analysis of individual patient data from prospective randomised trials from the Analysis and Research in Cancers of the Digestive 
FARMACIA, 2020, Vol. 68, 4

System (ARCAD) database. Lancet Oncol., 2016; 17(12): 1709-1719.

8. Gheorghe-Cetean S, Cainap C, Oprean L, Hangan A, Virag P, Fischer-Fodor E, Gherman A, Cainap S, Constantin AM, Laszlo I, Vlad C, Oprean R, Platinum derivatives: a multidisciplinary approach. J BUON., 2017; 22(3): 568-577.

9. Gulack BC, Nussbaum DP, Keenan JE, Ganapathi AM, Sun Z, Worni M, Migaly J, Mantyh CR, Surgical Resection of the Primary Tumor in Stage IV Colorectal Cancer Without Metastasectomy is Associated With Improved Overall Survival Compared With Chemotherapy/ Radiation Therapy Alone. Dis Colon Rectum., 2016; 59(4): 299-305.

10. Hecht JR, Mitchell E, Chidiac T, Scroggin C, Hagenstad C, Spigel D, Marshall J, Cohn A, McColum D, Stella P, Deeter R, Shahin S, Amado RG, A randomized phase IIIB trial of chemotherapy, bevacizumab, and panitumumab compared with chemotherapy and bevacizumab alone for metastatic colorectal cancer. J Clin Oncol., 2009; 27: 672-680.

11. Hsu HC, Liu YC, Wang CW, Chou WC, Hsu YJ, Chiang JM, Lin YC, Yang TS, Sequential cetuximab/ bevacizumab therapy is associated with improved outcomes in patients with wild-type KRAS exon 2 metastatic colorectal cancer. Cancer Med., 2019; 8(7): 3437-3446.

12. Hurwitz HI, Yi J, Ince W, Novotny WF, Rosen O, The clinical benefit of bevacizumab in metastatic colorectal cancer is independent of K-ras mutation status: analysis of a phase III study of bevacizumab with chemotherapy in previously untreated metastatic colorectal cancer. Oncologist, 2009; 14(1): 22-28.

13. Kumachev A, Yan M, Berry S, Ko YJ, Martinez MCR, Shah K, Chan KKW, A Systematic Review and Network Meta-Analysis of Biologic Agents in the First Line Setting for Advanced Colorectal Cancer. PLoS One, 2015; 10(10): e0140187: 1-14.

14. Labianca R, Nordlinger B, Beretta GD, Mosconi S, Mandala M, Cervantes A, Arnold D, ESMO Guidelines Working Group, Early colon cancer: ESMO Clinical Practice Guidelines for diagnosis, treatment and follow-up. Ann Oncol., 2013; 24(suppl_6): vi64-vi72.

15. Li J, Gupta M, Jin D, Xin Y, Visich J, Allison DE, Characterization of the long-term pharmacokinetics of bevacizumab following last dose in patients with resected stage II and III carcinoma of the colon. Cancer Chemother Pharmacol., 2013; 71(3): 575-580.

16. Mésange P, Poindessous V, Sabbah M, Escargueil AE, de Gramont A, Larsen AK, Intrinsic bevacizumab resistance is associated with prolonged activation of autocrine VEGF signaling and hypoxia tolerance in colorectal cancer cells and can be overcome by nintedanib, a small molecule angiokinase inhibitor. Oncotarget, 2014; 5(13): 4709-4721.

17. Mitry E, Guiu B, Cosconea S, Jooste JF, Bouvier $\mathrm{AM}$, Epidemiology, management and prognosis of colorectal cancer with lung metastases: a 30-year population-based study. Gut, 2010; 59(10): 1383-1388.

18. Modest DP, Stintzing S, von Weikersthal LF, Decker T, Kiani A, Vehling-Kaiser U, Al-Batran SE, Heintges T, Lerchenmuller C, Kahl C, Seipelt G, Kullmann F, Stauch M, Scheithauer W, Held S, Mohler M, Jung A, Kirchner T, Heineman V, Impact of subsequent therapies on outcome of the FIRE-3/AIO KRK0306 trial: first-line therapy with FOLFIRI plus cetuximab or bevacizumab in patients with KRAS wild-type tumors in metastatic colorectal cancer. J Clin Oncol., 2015; 33(32): 3718-3726.

19. Norguet E, Dahan L, Gaudart J, Gasmi M, Ouafik L, Seitz JF, Cetuximab after bevacizumab in metastatic colorectal cancer: is it the best sequence?. Dig Liver Dis., 2011; 43(11): 917-919.

20. Pavlidis ET, Pavlidis TE, Role of bevacizumab in colorectal cancer growth and its adverse effects: a review. World J Gastroenterol., 2013; 19(31): 50515060.

21. Pietrantonio F, Petrelli F, Coinu A, Di Bartolomeo M, Borgonovo K, Maggi C, Cabiddu M, Iacovelli R, Bossi I, Lonati V, Ghilardi M, de Braud F, Barni S, Predictive role of BRAF mutations in patients with advanced colorectal cancer receiving cetuximab and panitumumab: a meta-analysis. Eur J Cancer, 2015; 51(5): 587-594.

22. Stintzing S, Modest DP, Rossius L, Lerch MM, von Weikersthal LF, Decker T, Kiani A, Vehling-Kaiser U, Al-Batran SE, Heintges T, Lerchenmuller C, Kahl C, Seipelt G, Kullmann F, Stauch M, Scheithauer W, Held S, Giessen-Jung C, Moehler M, Jagenbuurg A, Kirchner T, Jung A, Heinemann V, FOLFIRI plus cetuximab versus FOLFIRI plus bevacizumab for metastatic colorectal cancer (FIRE-3): a post-hoc analysis of tumour dynamics in the final RAS wildtype subgroup of this randomised open-label phase 3 trial. Lancet Oncol., 2016; 17(10): 1426-1434.

23. Taniguchi H, Komori A, Narita Y, Kadowaki S, Ura T, Andoh M, Yatabe Y, Komori K, Kimura K, Kinoshita T, Muro K, A short interval between bevacizumab and anti-epithelial growth factor receptor therapy interferes with efficacy of subsequent anti-EGFR therapy for refractory colorectal cancer. Jpn J Clin Oncol., 2016; 46(3): 228-233.

24. Tol J, Koopman M, Cats A, Rodenburg CJ, Creemers GJ, Schrama JG, Erdkamp FLG, Vos AH, van Groeniingen CJ, Sinnige HAM, Richel DJ, Voest EE, Dijkstra JR, Vink-Borger ME, Antonini NF, Mol L, van Krieken JHJM, Dalesio O, Punt CJA, Chemotherapy, bevacizumab, and cetuximab in metastatic colorectal cancer. N Engl J Med., 2009; 360: 563-572.

25. Van Cutsem E, Cervantes A, Adam R, Sobrero A, Van Krieken JH, Aderka D, Aranda-Aguilar E, Bardelli A, Benson A, Bodoky G, Ciardiello F, D'Hoore A, DiazRubio E, Douillard JY, Ducreux M, Falcone A, Grothey A, Gruenberger T, Haustermans K, Heineman V, Hoff P, Kohne CH, Labianca R, Laurent-Puig P, Ma B, Maughan T, Muro K, Normanno N, Osterlund P, Oyen WJG, Papamichael D, Pentheroudakis G, Pfeiffer P, Price TJ, Punt C, Ricke J, Roth A, Salazar R, Scheithauer W, Schmoll HJ, Tabernero J, Taieb J, Tejpar S, Wasan H, Yoshino T, Zaanan A, Arnold D, ESMO consensus guidelines for the management of patients with metastatic colorectal cancer. Ann Oncol., 2016; 27: 1386-1422.

26. Venook AP, Niedzwiecki D, Lenz HJ, Innocenti F, Fruth B, Meyerhardt JA, Schrag D, Greene C, O'Neil BH, Atkins JN, Berry S, Polite BN, O’Reilly EM, Goldberg RM, Hochster HS, Schilsky RL, Bertagnolli MM, El-Khoueiry AB, Watson P, Benson AB, Mulkerin 
FARMACIA, 2020, Vol. 68, 4

DL, Mayer RJ, Effect of first-line chemotherapy combined with cetuximab or bevacizumab on overall survival in patients with KRAS wild-type advanced or metastatic colorectal cancer. JAMA., 2017; 317(23): 2392-2401

27. Wang J, Li S, Liu Y, Zhang C, Li H, Lai B, Metastatic patterns and survival outcomes in patients with stage IV colon cancer: A population-based analysis. Cancer Med., 2020; 9: 361-373.
28. Wang Y, Lei F, Rong W, Zeng Q, Sun W, Positive feedback between oncogenic KRas and HIF-1 $\alpha$ confers drug resistance in colorectal cancer. Onco Targets Ther., 2015; 8: 1229-1237.

29. Zheng B, Wang X, Wei M, Wang Q, Li J, Bi L, Deng $\mathrm{X}$, Wang Z, First-line cetuximab versus bevacizumab for RAS and BRAF wild-type metastatic colorectal cancer: a systematic review and meta-analysis. BMC Cancer, 2019; 19(1): 280: 1-12. 